\title{
Breastfeeding booklet in prison institutions: initiative for promotion, protection and support
}

\author{
Cartilha de amamentação nas instituições prisionais: iniciativa para promoção, proteção e apoio
}

Folleto de lactancia materna en instituciones penitenciarias: iniciativa de promoción, protección y apoyo

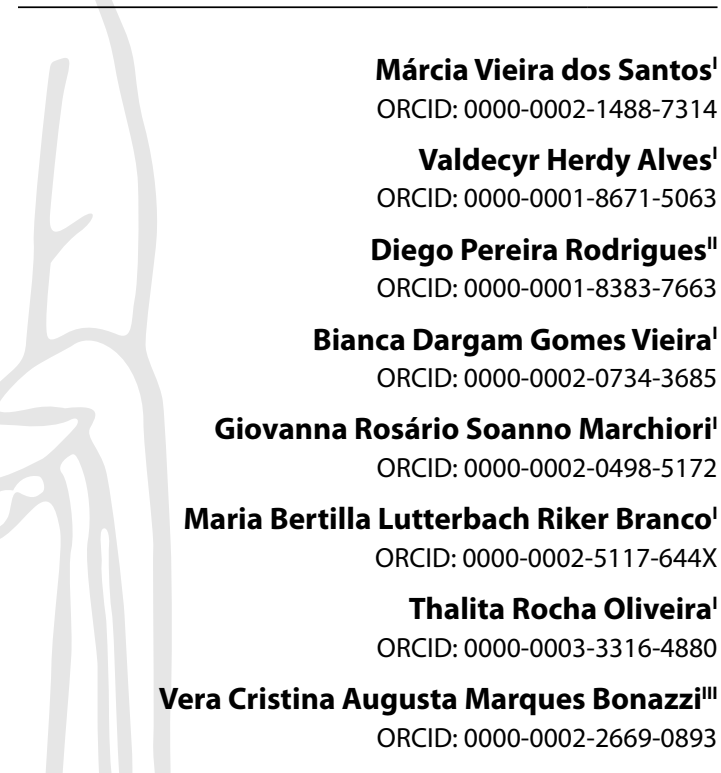

'Universidade Federal Fluminense. Niterói, Rio de Janeiro, Brazil. "Universidade Federal do Pará. Belém, Pará, Brazil. "'Hospital Sofia Feldman, Minas Gerais, Brazil.

How to cite this article: Santos MV, Alves VH, Rodrigues DP, Vieira BDG, Marchiori GRS, Branco MBLR, et al. Breastfeeding booklet in prison institutions: initiative for promotion, protection and support. Rev Bras Enferm. 2022;75(Suppl 2):e20210214. https://doi.org/10.1590/0034-7167-2021-0214

Corresponding author:

Diego Pereira Rodrigues

E-mail: diego.pereira.rodrigues@gmail.com

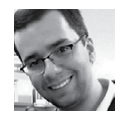

EDITOR IN CHIEF: Dulce Barbosa ASSOCIATE EDITOR: Hugo Fernandes

\begin{abstract}
Objectives: to understand the use of the booklet on breastfeeding in prison in times of COVID 19 by managers and health professionals who work with pregnant and breastfeeding women deprived of their liberty. Methods: this is a descriptive, exploratory research with a qualitative approach, carried out from March to December 2020. Thirteen professionals who work in Brazilian prison institutions participated in the study and answered a semistructured interview. The data obtained were submitted to content analysis. Results: the use of the booklet proved to be strategic in facing the barriers resulting from the pandemic and offered updated information and guidelines that are indispensable for the continuity of breastfeeding within the Brazilian prison system. Final Considerations: nursing participated in the organization of educational material as a tool for the promotion, protection and support of safe breastfeeding within the institutions of the prison system that serve pregnant and lactating women deprived of liberty.

Descriptors: Prisons; Infant; Breast Feeding; Nursing; Coronavirus Infections.
\end{abstract}

\section{RESUMO}

Objetivos: compreender a utilização da cartilha de amamentação no cárcere em tempos de COVID-19 pelos gestores e profissionais de saúde que atuam com gestantes e lactantes privadas de liberdade. Métodos: trata-se de pesquisa descritiva, exploratória, com abordagem qualitativa, realizada no período de março a dezembro de 2020. Participaram do estudo 13 profissionais que trabalham em instituições prisionais brasileiras e responderam à entrevista semiestruturada. Os dados obtidos foram submetidos à análise de conteúdo. Resultados: a utilização da cartilha se mostrou estratégica no enfrentamento das barreiras advindas da pandemia e ofertou informações e orientações atualizadas indispensáveis para a continuidade da amamentação dentro do sistema prisional brasileiro. Considerações Finais: a enfermagem participou na organização de material educativo como uma ferramenta na promoção, proteção e apoio à amamentação segura dentro das instituições do sistema prisional que atendem gestantes e lactantes privadas de liberdade.

Descritores: Prisões; Lactante; Aleitamento Materno; Enfermagem; Infecções por Coronavírus.

\section{RESUMEN}

Objetivos: comprender la utilización de la cartilla de lactancia en el cárcel en tiempos de COVID-19 por gestores y profesionales de salud que actúan con gestantes y lactantes privadas de libertad. Métodos: discurre de investigación descriptiva, exploratoria, con abordaje cualitativo, realizada entre marzo a diciembre de 2020. Participaron del estudio 13 profesionales que trabajan en instituciones carcelarias brasileñas y respondieron a la entrevista semiestructurada. Los datos obtenidos fueron sometidos al análisis de contenido. Resultados: la utilización de la cartilla se mostró estratégica en el enfrentamiento de las barreras advenidas de la pandemia y ofreció informaciones y orientaciones actualizadas indispensables para la continuidad de la lactancia dentro del sistema carcelario brasileño. Consideraciones Finales: la enfermería participó en la organización de material educativo como una herramienta en la promoción, protección y apoyo a la lactancia segura dentro de las instituciones del sistema carcelario que atienden gestantes y lactantes privadas de libertad. Descriptores: Prisiones; Lactante; Lactancia Materna; Enfermería; Infecciones por Coronavirus. 


\section{INTRODUCTION}

On January 30, 2020, the World Health Organization (WHO) reported that the disease COVID-19, caused by the novel coronavirus (SARS-CoV-2), was a public health emergency of international importance. On March 11 of the same year, the WHO declared COVID-19 a global pandemic ${ }^{(1)}$. According to the Epidemiological Bulletin of the Secretariat of Surveillance of the Ministry of Health $(\mathrm{MH})$, dated April 6, 2020, some preventive measures, such as social distancing, respiratory etiquette and hand washing, were adopted to prevent the spread of this virus in the Brazilian population ${ }^{(2)}$.

With this virus circulating worldwide, it was necessary to program norms, protocols, and resolutions about the practice of breastfeeding in times of COVID-19, based on the publication of the WHO and the Center for Disease Control and Prevention (CDC), which informed that there was no proof that human milk spread the new coronavirus. Therefore, the guidelines for maintaining breastfeeding in times of pandemic were unanimous in scientific publications ${ }^{(2-3)}$.

In case a woman is infected during the lactation period and wishes to continue breastfeeding, it is recommended: wash your hands for 20 seconds, wear a mask when breastfeeding, do not talk during breastfeeding, change the mask if it is dirty. In addition, if the woman wishes, she can remove the milk and store it, according to strict guidelines for this practice; and, if possible, it is recommended to have someone helping her at this time ${ }^{(3-10)}$.

Facing the COVID-19 pandemic, the Ministry of Justice and Public Safety, through the National Penitentiary Department (DEPEN), implemented protocols with the adoption of measures to prevent the transmission of the new coronavirus in the prison environment ${ }^{(10-11)}$. In this sense, the National Council of Justice made recommendation No. 62 of March 17, 2020, suggesting the adoption of preventive measures for the spread of COVID-19 in prison spaces, in order to ensure, during this period, the integrity of people living in this environment ${ }^{(12)}$.

It must be taken into consideration that breastfeeding in prison is challenging because of its complexity, due to the specificities of the prison population, besides being a very vulnerable environment and with little support for this practice ${ }^{(13)}$. Some factors that hinder the act of breastfeeding correspond to the unhealthy environment, separation from family members, abandonment by family members, and educational condition $s^{(14)}$.

On March 13,2020, visitation in the prisons of the state of Rio de Janeiro was suspended by Decree No. 46,970, impacting field research under development and to be developed in these spaces. Due to this administrative measure, the work, in an unfinished stage, entitled "Lactating women and the axiological understanding of breastfeeding in prison settings" was interrupted indefinitely, which enabled the construction of strategies to face the pandemic, collaborating in the promotion of breastfeeding in the prison system. Nursing was present from the perspective of an educational intervention, through the organization of didactic material that allowed the promotion of breastfeeding in these institutions.

Thus, a booklet entitled "Breastfeeding in prison in times of COVID-19" was produced, focusing on the promotion of breastfeeding in the spaces of Brazilian penal institutions that work with lactating women deprived of liberty, during the period of the COVID-19 pandemic. This strategic tool was presented, via e-mail, for consideration and approval by the following institutions: Maternity Research Group:Women and Children's Health - Federal Fluminense University (UFF), consisting mostly of nurses; DEPEN; Milk Bank of the Antônio Pedro University Hospital, under the coordination of a professional nurse; and the Brazilian Company of Hospital Services (EBSERH).

The booklet was developed in dialogue with the WHO, CDC, Technical Standards of the MH, the Brazilian Federation of Associations of Gynecology and Obstetrics, the Brazilian Society of Pediatrics, the Brazilian Association of National Nursing, the Brazilian Network of Human Milk Banks of Fiocruz, and the Protocol for Clinical Management of Coronavirus (COVID-19) in Primary Health Care ${ }^{(1-10)}$.

The booklet was reproduced in print and also in virtual format. It totals 24 pages and contains information to reduce the risks of transmission of the new coronavirus, in addition to encouraging breastfeeding in this period within the prison context. It was important to print the booklets, because only then could the women who were inside the prison system have access to the educational material, since the virtual version is not allowed inside Brazilian prisons.

\section{OBJECTIVES}

To understand the use of the booklet on breastfeeding in prison in times of COVID 19 by managers and health professionals who work with pregnant and breastfeeding women deprived of their liberty.

\section{METHODS}

\section{Ethical Aspects}

The study was approved by the Ethics and Research Committee of the UFF School of Medicine. After presentation of the scope, the participants were oriented about the research in general, benefits and risks, and invited to participate. To preserve confidentiality, anonymity, and reliability, the interviewees were identified with the letter (I) for "interviewee", followed by a number corresponding to the sequence in which the interviews were conducted $(11,12$, 13... 113), plus, the guarantee of voluntary participation by signing the Free and Informed Consent Term. If necessary, a psychology professional from the Maternity Research Group: Women's and Children's Health (UFF) would be available to monitor the participant, as determined by Resolution CNS 466/12.

\section{Type of study}

This is a descriptive, exploratory research with a qualitative approach, guided by the Consolidated Criteria for Reporting Qualitative Research (COREQ) instrument.

\section{Study scenario}

The scenario of this research was Brazilian institutions that work with pregnant and lactating women deprived of liberty and/or at home. The institutions that received the booklet by mail are from the following states: Santa Catarina (1), Mato Grosso (2), São Paulo (1), Paraná (1), Bahia (1), Sergipe (1), Rio Grande do Sul (1), Espírito Santo (2), Distrito Federal (1) and Rio de Janeiro (2). 


\section{Data Sources}

The participants were 13 professionals from institutions linked to the Brazilian penitentiary system, who met the following inclusion criteria: working in institutions with pregnant and lactating women serving sentences in the closed system or serving sentences at home, state maternal and child reference centers of the penal system and institutions called "custody hearings". The exclusion criteria established were: professionals from women's institutions whose pregnant and lactating women were awaiting transfer and from women's institutions that served pregnant and lactating women, but did not have maternity and child units.

Contact was made via e-mail with the units that received the booklet, requesting that the professionals of the institution answer an online interview. Thus, the researcher invited, via e-mail, the professionals to participate in the research, and the recruitment was done according to the convenience of the participants ${ }^{(15)}$. The study sample size was established by the saturation process ${ }^{(16)}$, when there is repetition of meanings of the participants' statements.

It should be noted that it was not possible to perform the initial welcome in each scenario, but there was the use of a communicative e-mail in order to establish an informative relationship about the study. It is worth mentioning that none of the participants knew about the personal objectives and characteristics of the interviewer, nor was there any relational movement with the institutions to carry out the study. We followed only the interest related to the problem of the study, and not the interests of the institutions or the interviewees.

\section{Collecting and organizing data}

Data was collected from March to December 2020, via e-mail, by answering the semi-structured interview instrument with open and closed questions that helped researchers analyze the booklet as a tool for the promotion, protection, and support of breastfeeding in the Brazilian prison system. The instrument contained questions on the characterization of the professionals in the institution and the following research question: "In what way did the educational material contribute to the confrontation of barriers arising from the COVID-19 pandemic? And how did it provide updated information and guidance for managers and health professionals regarding the maintenance of breastfeeding?" The instrument was returned to the researcher's e mail, making it possible to meet the research objective. All the material sent was submitted to data treatment and analysis.

In this study, asynchronous online collection strategies were used, that is, the participant has access to the survey at the time he or she is available. The researcher monitors the responses as they are posted, and the online data collection is mapped for future analysis ${ }^{(17)}$.

It is noteworthy that the researcher has a master's degree and presents mastery of the interview technique and instruments applied online, since she received all the training from doctoral members of the research team. In addition, she has experience in applying the interview in other studies.

\section{Data analysis}

In the data analysis, the treatment was based on content analysis ${ }^{(18)}$ with the objective of discovering the content of the manifest discourse, in three moments: 1) pre-analysis of the statements (organization of the material, with floating reading, with choice of documents to be analyzed [a priori]; or select from those collected [a posteriori] - construction of the corpus based on exhaustiveness, representativeness, homogeneity and relevance, formulations of hypotheses or objectives and preparation of the material); 2 ) exploration of the material and treatment of the results (coding and categorization of the material - coding is the cut made of the meaning units, which can be words, the theme, the object or something related to the event, and to select the units, the pertinence must be taken into consideration, and the frequency or occurrence can be obtained, called "contingency analysis"; the categorization will follow the semantic, syntactic, lexical or expressive criteria); 3) inference and interpretation (interpretation of the results obtained, based on the inference, constituting a type of controlled interpretation, which may be based on the constituent elements of the classic mechanism of communication - message, meaning, code, sender and receiver) ${ }^{(18)}$.

Thus, the data was sorted with the transcription of the interviews in full, and a floating reading and grouping was performed, subjecting them to detailed and exhaustive analysis and comparing them with the scientific literature. In the second level, the units of analysis (units of meaning: breastfeeding and knowledge) were selected, appearing by means of their frequency (repetition of meanings), namely: breastfeeding doubts (F35\%); breastfeeding safety (F28\%); women's right (F31\%); scientific knowledge to the object (F41\%); special care (F30\%); good breastfeeding practices (F25\%); breastfeeding promotion, protection, and support (F38\%). In the last phase of the analytical process, the meaning units were identified, which enabled the categorization of the constructive elements and the regrouping of the meanings, based on the non-aprioristic categorization. This emerged from the context of the participants' answers, which were the basis for the construction of the following categories: 1) The booklet as a tool to face the pandemic of COVID-19 and to promote, protect, and support breastfeeding; 2) The booklet as a public policy strategy to promote, protect, and support breastfeeding; and 3) Nursing as a promoter of knowledge about breastfeeding and clarification of doubts in the context of the COVID-19 pandemic.

\section{RESULTS}

When analyzing the results, it was observed that the profiles of the establishments of the professionals who answered the interviews correspond to: six exclusive institutions for pregnant and lactating women in closed regime; four "mixed" institutions in closed regime, that is, a mixed institution is not an exclusive institution for the puerperal period, but a specific space is reserved in the prison unit for pregnant and lactating women deprived of liberty; two institutions were state reference centers for mothers and children; and one institution was a custody hearing.

Regarding the professionals of the institutions who answered the interview, five were directors (managers) of prison units and eight were health professionals, being seven nurses and one social worker. 
The booklet as a tool to confront the pandemic of COVID-19 and to promote, protect and support breastfeeding

The speeches indicated that the booklet presented a good organization of information, maintaining a close dialogue with the context of the pandemic of COVID-19 and was an important tool for the breastfeeding prison population to understand how to proceed in facing this disease. Still, it is inferred that, in the face of a concern present in this group of women and caused by the pandemic, the arrival of this material helped to alleviate this anguish, as observed in the following excerpts:

It removed the doubts regarding breastfeeding and COVID-19. The booklet is well elaborated. (16)

We held a conversation circle, distributed the material to the women, and all existing doubts were removed. We want them to continue to breastfeed, if they want to. We give support. (I1)

The booklet helped to clear up cross-information doubts at the present time of the pandemic. This makes all the difference. (18)

It brought accurate information about the importance of maintaining breastfeeding, even during the pandemic of COVID-19, gave us more security. (110)

In this process of promotion, protection, and support to breastfeeding in prison institutions that serve the female public, the booklet brought safety to lactating and pregnant women. According to the interviewees, the information provided access to knowledge about good practices for not spreading COVID-19, the need for hand hygiene during the whole act of breastfeeding, the use of a mask, and, mainly, the importance of breastfeeding for the baby and the mother. According to the speeches, the booklet had a positive impact on this public:

The booklet offers reassurance to women who breastfeed and to those who will breastfeed. This makes a difference in everyday life. (12)

It brought knowledge of best practices and reinforced the need for special care during the pandemic, as well as being a reference material. (13)

It guides the work of the health professional, teaching how to stop the contagion of the disease from individual to individual, a consultation tool for women and for professionals. (17)

Therefore, this educational material was a tool that strengthened the promotion of breastfeeding in prison in times of COVID-19 and inspired women to breastfeed during the pandemic.

Thus, it is understood that there must be not only promotion, protection and support actions prioritizing the maintenance of breastfeeding within prisons, but also adequate policies and infrastructure that protect breastfeeding in this environment.

\section{The booklet as a public policy strategy to promote, protect and support breastfeeding}

The use of the booklet is configured as a strategy to value women, to reinforce the right to breastfeeding even for the vulnerable population subjected to deprivation of liberty. This viable idea is defended as a public policy of promotion, protection, and support to breastfeeding. The interviewees express interest in the esteem and attention given to inmates, stating that the booklet provided a meeting with this perspective of attention to the needs of this specific public, as presented in the statements:

In addition to knowledge, it reinforced to the women the importance of breastfeeding in prison, and also helped us to better understand breastfeeding in this period of COVID-19. (18)

It was delivered to all private pregnant and lactating women and to all health professionals. It made a difference, because we had a lot to discuss and take questions. It improved the process of breastfeeding. (17)

Besides feeling valued and cared for, the women had the opportunity for learning and knowledge. This was very good here. (I3)

Besides contemplating this dimension of the human and fostering a public policy to face the pandemic, the material prepared allowed the information to go beyond the prison walls and reach family members and even wives of inmates from other establishments. It is noticeable that the booklet was also important for the professionals involved in the health care of these women, which is expressed in the following statements:

For the professionals, it brought new instructions about breastfeeding, which helped us a lot in our practice. (15)

We needed to share it as a PDF for all healthcare professionals working in the prison system. This strengthens care. (14)

It was distributed not only to pregnant and lactating women, but also to the wives of inmates who are pregnant and/or breastfeeding. We can expand the network. (I8)

Thus, to promote breastfeeding in the women's prison units in times of COVID-19 and to remove the barrier to breastfeeding, strategies were created by managers and health professionals to face the pandemic.

The WHO emphasizes the importance of everyone's support and the construction of partnerships at this time to confront the infection of COVID-19 in prison spaces. It also recalls that public health actions must be carried out without any kind of discrimination, because people deprived of their liberty are already vulnerable to the disease and should not suffer any violation of human rights.

\section{Nursing as a promoter of knowledge about breastfeeding and clarification of doubts in the context of the pandemic of COVID-19}

The speeches pointed to the important role of nursing in the preparation of the booklet and evidenced the uses of this material by the management team of women's prisons. Both the professionals involved in monitoring the health care of inmates and the prison population itself were benefited by the booklet. This is what the following statements indicate:

A health education action of easy language, dynamic, with clarifications for staff on how to properly deal with breastfeeding 
women and babies during the pandemic of COVID-19. It made all the difference, extends and gives continuity for breastfeeding up to six months. (I12)

The material was distributed directly to the women deprived of liberty and then the material was read together with the women and the health professionals, to remove any doubts. This made it easier to implement the discussion about the breastfeeding time, from six months to two years, completing it with food. This makes a difference and brings security for the baby's growth. (12)

Because of the very small number of pregnant and lactating inmates, the distribution was timid, the booklet was left in the Nursing sector so that new pregnant or lactating inmates could have access to the information. This helped a lot. (111)

As can be observed, the material achieved a good acceptance by this group and fostered educational actions within the prison institutions. This printed material provided consistent actions to face the pandemic of COVID-19, as well as guaranteed to these women the right to breastfeed. The booklet was considered an important tool in the promotion, protection, and support of breastfeeding.

We gave it to the women initially and, as others arrived, they received it separately. They were very receptive to the material. We distributed it to pregnant and lactating women, [...] it helped us make sense of the need to continue breastfeeding; it's good for her and the baby. (13)

They all show a lot of interest in the subject. This has helped our work here. (I10)

Brought new knowledge to managers, professionals, and to women deprived of their liberty. (12)

Thus, the booklet was designed to provide relevant instructions on breastfeeding in the pandemic and to be a tool to promote the continuation of breastfeeding in prison during the pandemic of COVID-19.

The results indicated that, for the incarcerated population, the booklet was a strengthening instrument for the promotion of breastfeeding in prison in times of COVID-19. The research participants evaluated that the clarifications contained in the material made it possible to guarantee, for this female prison population, the right to breastfeeding, being, therefore, a pertinent strategy to face the pandemic.

\section{DISCUSSION}

The activities to encourage breastfeeding should occur within the prison system through promotional actions developed by professionals who have updated information, to help in the decisions and the positive impact of breastfeeding in prison ${ }^{(19-20)}$. This is because when these professionals are qualified, it is possible to better promote and support breastfeeding ${ }^{(20)}$, since such promotion is important in transforming reality and contributing to the reduction of inequalities ${ }^{(21)}$.

It is up to the nurse to develop breastfeeding promotion activities within the prison environment ${ }^{(13)}$, but the support of a multidisciplinary team is essential to offer knowledge to the lactating woman, ensuring that she feels safe when making assertive decisions ${ }^{(20)}$. Therefore, it is worth noting that with the increase in the professionals' skills, there is an improvement in care and, in turn, a better result regarding breastfeeding ${ }^{(22-23)}$. Given the difficulties of breastfeeding in prison, it is essential that professionals support women who breastfeed and clarify their doubts, because the more information is offered, the more the woman will be prepared to breastfeed in prison ${ }^{(20)}$.

The United Nations Children's Fund (UNICEF) suggests that, in the face of the COVID-19 pandemic, international human rights standards on juvenile justice be used and alternative measures or measures of freedom be applied. In cases where these are not possible, adequate measures should be offered to attend to this population, especially for mothers who are breastfeeding ${ }^{(24)}$. Therefore, in prison, the challenge of continuing breastfeeding should follow the recommendations of international and national bodies, with updated information and preventive measures against the spread of this virus in the environment where there are pregnant and lactating women deprived of liberty ${ }^{(2-3)}$.

To increase and encourage the continuity of breastfeeding, some interventions are necessary, among which individual or collective counseling, which support women and increase the practice of breastfeeding, because health promotion removes cultural and social barriers that hinder breastfeeding ${ }^{(25)}$. In this context, during the pandemic of COVID-19, every pregnant and lactating woman needs quality care for her needs in an integral and humanized manner ${ }^{(26)}$. However, for this, it is necessary that the professionals have up-to-date information and training, so that they can make decisions based on scientific evidence ${ }^{(27)}$.

All the movements for the promotion, support, and protection of breastfeeding are promoted to avoid early weaning, which brings several and serious consequences for children, especially in underdeveloped countries where diarrhea, severe malnutrition, and a large number of infections occur, causing an increase in infant deaths. We must remember that breastfeeding brings benefits to the mother, the child, and the society. In addition, it increases the affective bond between mother and child, increases affection and trust between them, and improves the family's quality of life, because the breastfed child gets sick less, which brings greater emotional stability to everyone ${ }^{(28)}$.

As for the safety of breastfeeding in times of pandemic, the $\mathrm{MH}$, based on the $\mathrm{WHO}$ and $\mathrm{CDC}$ guidelines, states that, until the moment, breastfeeding should be maintained due to the protection that breast milk offers against other diseases. Therefore, it is necessary that professionals are qualified to convey information to pregnant and lactating women, so that they can have the power of decision whether or not to breastfeed during this period. If they so wish, it is essential to adopt control measures not to spread the new coronavirus to their babies ${ }^{(29)}$.

Reflecting on the promotion of breastfeeding in prison in times of COVID-19 is complex, because the lactating woman already suffers several physical, psychological, and hormonal alterations, which, within the prison system, can turn into diseases. Thus, the prison system promotes a risk that undermines the bond between mother and child, and this occurs due to the environment, the lack of support and health promotion actions offered to this public ${ }^{(30)}$. It is observed that, in order to adhere to 
the practice of breastfeeding in prison, permanent educational actions and promotion and support strategies are necessary to enable women to overcome their difficulties, improve their skills, and learn the importance of continuing breastfeeding. Only then will this woman make conscious decisions related to the care of her health and that of her baby, thus understanding that the woman is the protagonist in the process at this moment ${ }^{(22)}$.

Under such a perspective, for breastfeeding to happen within the prison system, it should be stimulated with promotional actions prioritizing the benefits for the woman and the child, in order to offer security for those involved in this process and maintain the referred act in these institutions ${ }^{(31)}$. Although breastfeeding is considered natural and physiological, it is necessary to teach, learn, support and encourage its practice continuously ${ }^{(32)}$.

Therefore, we understand the need to develop health actions that guarantee the lactating woman self-confidence to breastfeed in prison ${ }^{(30)}$. However, to work in prisons as a health educator, it is essential to break several paradigms, so that women's decisions about breastfeeding are responsible. To do so, professionals need to promote knowledge about breastfeeding, because, through information, people are transformed, they change their practices, their way of thinking and acting ${ }^{(33)}$.

In this sense, the booklet "Breastfeeding in prison in times of COVID-19" proved to be an initiative that instrumentalized and provided an opportunity to promote breastfeeding using a methodology that met the demands of the target population, bringing new knowledge and clarifying doubts. Thus, it shows the importance of continuing breastfeeding in the pandemic period and safely inside the prison environment. Furthermore, the booklet was also a tool that managed to generate a new perspective of conducting the topic beyond prisons, exceeding its objective through the proposal of sending it to other professionals who also work in the prison system, with a view to expanding knowledge on the subject.

For the continuity of breastfeeding in the prison system, breastfeeding promotion actions are fundamental ${ }^{(34)}$. Along these lines, the booklet complied with the principle of equity as determined by the Unified Health System, promoting health actions within the Brazilian prison system, working and disseminating information without prejudice or privileges of any kind. Yet, another advance of this work was presented: the possibility of health professionals discussing with pregnant and lactating women in prison the importance of breastfeeding in times of COVID-19.

\section{Study limitations}

The limitations consist in the impossibility of: expanding the institutions of the national prison system, due to the nonparticipation of all the federative units; and to affirm that there was privacy for the participants to answer the semi-structured interview, since there was no meeting in a physical space, since the research instrument was answered online.

Also, because the methodological study of the validation of the booklet was not presented, there was a limitation, which was minimized by the appreciation and approval of the booklet by professionals with competence in the area and with shared work on the theme.

\section{Contributions to the field of Nursing}

New research can be developed with this theme and population, since we still need to investigate the receptivity of women who had access to this material, so that it can then be improved and adapted to the contexts of each Brazilian region. It is also relevant to verify if the multi-professional work can broaden the view of different educational materials on other health topics.

It is also revealed that the booklet is a public policy strategy for other collective health campaigns, which corroborate the desire of the incarcerated female population. According to the narratives, there is a longing for the elaboration of new educational materials, in the same model of the booklet, for the promotion of the health of pregnant and lactating women deprived of freedom, with the following themes: sexually transmitted infections, breast cancer, and mental health. Nursing, by turning its eyes to this vulnerable population, fulfills its mission to exercise care and attention to the health of all as a universal right.

\section{FINAL CONSIDERATIONS}

The booklet "Breastfeeding in prison in times of COVID-19" proved to be an effective tool according to managers and health professionals who work with pregnant and lactating women deprived of liberty. In the evaluation of this group, the content, with accessible language and easy to understand by the incarcerated female audience, was enlightening as to the maintenance of breastfeeding, as well as effective in resolving some doubts regarding the implications of COVID-19 for the mother-baby binomial.

This educational material can be considered appropriate for the promotion of breastfeeding with managers and health professionals in the prison system, as it was a strategic tool in addressing the challenges of COVID-19. It provided safe guidelines on the proper care for the continuity of breastfeeding within the prison system, demonstrating in an illustrative and conceptual way that breast milk is the safest food for the child, even in the period experienced worldwide.

Nursing was present throughout the process of this experience. The nurse researcher, in contact with the managers of the prisons that serve women inmates or women subjected to measures of deprivation of liberty, presented the proposal supported by the Research Group Maternity: Women's and Children's Health - UFF. Given the acceptance, the educational actions of nursing for the promotion, protection, and support of breastfeeding were organized in this material, aiming to inform about the benefits of breastfeeding, clarify doubts about the impacts of COVID-19, and share the necessary actions to guarantee the rights of women to exercise their will to maintain breastfeeding, even during the pandemic.

\section{FUNDING}

Carlos Chagas Filho Foundation for Research Support of the State of Rio de Janeiro - FAPERJ.

Coordination for the Improvement of Higher Education Personnel. 


\section{REFERENCES}

1. World Health Organization. Coronavirus Disease (Covid-19) Pandemic [Internet]. 2020 [cited 2020 Apr 06]. Available from: https://www. paho.org/pt/covid19/historico-da-pandemia-covid-19

2. Ministério da Saúde (BR). Secretaria de Vigilância em Saúde. Boletim Epidemiológico. Centro de Operações Emergenciais em Saúde Pública. Doença pelo Coronavírus 2019. Semana epidemiológica. Brasília: Ministério da Saúde [Internet]. 2020 [cited 2020 Apr 06]. Available from: https://www.saude.gov.br/images/pdf/2020/April/06/2020-04-06-BE7-Boletim-Especial-do-COE-Atualizacao-da-Avaliacao-de-Risco.pdf

3. Center for Disease Control and Prevention (CDC). Care for Breastfeeding Women: Interim Guidance on Breastfeeding and Breast Milk Feeds in the Context of covid-19 [Internet]. 2021 [cited 2021 Mar 16]. Available from: https://www.cdc.gov/coronavirus/2019-ncov/hcp/care-forbreastfeeding-women.html

4. Sociedade Brasileira de Pediatria. O Aleitamento materno nos tempos de covid-19 [Internet]. 2020 [cited 2020 Mar 16]. Available from: https://www.sbp.com.br/fileadmin/user_upload/22393c-Nota_de_Alerta_sobe_Aleitam_Materno_nos_Tempos_COVID-19.pdf

5. Ministério da Saúde (BR). Secretaria de Atenção Primária à Saúde Departamento de Ações Programadas Estratégicas. Nota Técnica no 7/2020- DAPES/SAPS/MS2020 [Internet]. 2020 [cited 2020 Apr 17]. Available from: http://www.saude.df.gov.br/wp-conteudo/ uploads/2018/02/SEI_MS-0014033399-Nota-Te\%CC\%81cnica-Aleitamento-e-COVID.pdf

6. Federação Brasileira das Associações de Ginecologia e Obstetrícia. Complementação à extensa revisão publicada pelas Comissões Nacionais Especializadas (CNE) da FEBRASGO em Assistência Pré-Natal e Doenças Infecto-Contagiosas [Internet]. 2020 [cited 2020 Mar 18]. Available from: https://www.febrasgo.org.br/pt/noticias/item/949-notulacomplementar-sobre-covid-19-e-aleitamento-materno

7. Ministério da Saúde (BR). Fundação Oswaldo Cruz. Rede Brasileira de Bancos de Leite Humano. Recomendação Técnica № 01/20.170320. Assunto: covid-19 e Amamentação. Brasília: Ministério da Saúde [Internet]. 2020 [cited 2020 Apr 12]. Available from: https://rblh.fiocruz.br/ sites/rblh.fiocruz.br/files/usuario/80/rblh_recomendacao_01020_170320.pdf

8. Ministério da Saúde (BR). Secretaria de Atenção Primária à Saúde Departamento de Ações Programadas Estratégicas. Nota Técnica no 10 /2020- DAPES/SAPS/MS2020 [Internet]. 2020 [cited 2020 Apr 14]. Available from: http://www.ibfan.org.br/site/wp-content/ uploads/2020/04/NOTA-T\%C3\%89CNICA-N-10-2020-COVID19-RECEM-NASCIDO.pdf

9. Ministério da Saúde (BR). Rede Brasileira de Bancos de Leite Humano. Covid-19: rBLH divulga recomendações sobre amamentação [Internet]. 2020 [cited 2020 Apr 14]. Available from: https://portal.fiocruz.br/noticia/ covid-19-rblh-divulga-recomendacoes-sobre-amamentacao

10. Ministério da Saúde (BR). Secretaria de Atenção Primária à Saúde (SAPS). Protocolo de Manejo Clinico do Coronavírus (COVID-19) na Atenção Primária à Saúde[Internet]. 2020 [cited 2020 Apr 12]. Available from: https://saude.rs.gov.br/upload/arquivos/202004/14140606-4ms-protocolomanejo-aps-ver07abril.pdf

11. Ministério da Justiça e da Segurança Pública (BR). Levantamento Nacional de Informações Penitenciárias [Internet]. 2020 [cited 2020 Apr 12]. Available from: https://www.justica.gov.br/news/estudo-traca-perfil-da-populacao-penitenciaria-feminina-no-brasil/relatorio-infopenmulheres.pdf

12. Ministério da Justiça (BR). Conselho Nacional de Justiça. Portaria № 62, de 17 de março de 2020. [Internet]. 2020 [cited 2020 Apr 17 ]. Available from: https://atos.cnj.jus.br/atos/detalhar/3246https://atos.cnj.jus.br/atos/detalhar/3246

13. Medeiros AN, Ferreira BMV, Costa LVF, Silva JCB, Guerra MCGC, Albuquerque NLA. Aleitamento materno no sistema penitenciário: sentimentos da lactante. Rev Ciênc Plur. 2020;6(1):18-31. https://doi.org/10.21680/2446-7286.2020v6n1ID18255

14. Cavalcanti AL, Costa GMC, Celino SDM, Corrêa RR, Ramos RA, Cavalcanti AFC. Born in chains: perceptions of Brazilian mothers deprived of freedom about breastfeeding. Pesq Bras Odontoped Clin Integr. 2018;18(1):e4144. https://doi.org/10.4034/PBOCI.2018.181.69

15. Patias ND, Hohendorff JV. Critérios de qualidade para artigos de pesquisa qualitativa. Rev. Psicologia em Estudo. 2019;24:e43536. https:// doi.org/10.4025/psicolestud.v24i0.43536

16. Nascimento LCN, Souza TV, Oliveira ICS, Moraes JRMM, Aguiar RCB, Silva LF. Theoretical saturation in qualitative research: an experience report in interview with schoolchildren. Rev Bras Enferm. 2018;71(1):243-8. https://doi.org/10.1590/0034-7167-2016-0616

17. Salvador PTCO, Alves KYA, Rodrigues CCFL, Oliveira LV. Estratégias de coleta de dados online nas pesquisas qualitativas da área da saúde: scoping review. Rev Gaúcha Enferm. 2020;41:e20190297. https://doi.org/10.1590/1983-1447.2020.20190297

18. Bardin L. Análise de conteúdo. Lisboa: Edições 70; 2011.

19. Organização Mundial de Saúde. Preparedness, prevention and control of COVID-19 in prisons and other places of detention [Internet]. 2021 [cited 2020 Apr 17]. Available from: https://apps.who.int/iris/bitstream/handle/10665/339830/WHO-EURO-2021-1405-41155-57257-eng. pdf?sequence $=1$ \&isAllowed $=y$

20. Guimarães ML, Guedes TG, Lima LS, Morais SCRV, Javorski M, Linhares FMP. Promoção do aleitamento materno no sistema prisional a partir da percepção de nutrizes encarceradas. Texto Contexto Enferm. 2018;24(4):e3030017. https://doi.org/10.1590/0104-07072018003030017

21. Victora CG, Bahl R, Barros AJ, França GV, Horton S, Krasevec J, et al. Breastfeeding in the 21st century: epidemiology, mechanisms, and lifelong effect. Lancet. 2016;387(10017):475-90. https://doi.org/10.1016/S0140-6736(15)01024-7 
22. Costa EFG, Alves VH, Souza RMP de, Rodrigues DP, Santos MV, Oliveira FL de. Atuação do enfermeiro no manejo clínico da amamentação: estratégias para o aleitamento materno. Rev Pesqui Cuid Fundam [Internet]. 2018 [cited 2020 Apr 17];10(1):217-23. Available from: http:// www.seer.unirio.br/cuidadofundamental/article/view/5953

23. Oakley L, Benova L, Macleod D, Lynch CA, Campbell OMR. Early breastfeeding practices: descriptive analysis of recent demographic and health surveys. Matern Child Nutr [Internet]. 2018 [cited 2020 Apr 17];14(2):e12535. https://doi.org/10.1111/mcn.12535

24. Fundo das Nações Unidas para a Infância. Nota Técnica: covid-19 e Crianças e Adolescentes em Privação de Liberdade [Internet]. 2020 [cited 2021 Aug 17]. Available from: https://www.unicef.org/brazil/sites/unicef.org.brazil/files/2020-05/covid-19-criancas-adolescentes-privacaoliberdade.pdf

25. Rollins, NC, Lutter CK, Bhandari N, Hajeebhoy N, Horton S, Martines JC, et al. Why invest, and what it will take to improve breastfeeding practices? Epidemiol Serv Saúde. 2016;25(1):491-504. https://doi.org/10.1016/S0140-6736(15)01044-2

26. Souza KV, Schneck SC, Pena ED, Duarte ED, Alves VH. Direitos humanos das mulheres no parto frente à pandemia de covid-19: o que fazer da enfermagem obstétrica. Cogitare Enferm. 2020;25:e73148. https://doi.org/10.5380/ce.v25i0.73148

27. Rondelli G, Jardim D, Hamad G, Luna E, Marinho W, Mendes L, et al. Assistência às gestantes e recém-nascidos no contexto da infecção por covid-19: uma revisão sistemática. Rev Desafios. 2020;7(spe 3):48-74. https://doi.org/10.20873/uftsuple2020-8943

28. Ministério da Saúde (BR). Secretaria de Atenção à Saúde. Departamento de Atenção Básica. Coordenação-Geral de Alimentação e Nutrição. Informe situacional sobre os Programas de alimentação e nutrição e de promoção da saúde na atenção básica. Brasília: Ministério da Saúde [Internet]. 2017 [cited 2020 Apr 16]. Available from: http://189.28.128.100/dab/docs/portaldab/documentos/Informe_Situacional_Geral.pdf

29. Ministério da Saúde (BR). Secretaria de Atenção Primária à Saúde. Perguntas Frequentes - Amamentação e COVID-19. 29 [Internet]. 2020 [cited 2020 Apr 16]. Available from: https://portaldeboaspraticas.iff.fiocruz.br/biblioteca/ perguntas-frequentes-amamentacao-e-covid-19-ms/

30. Santos, MV, Alves VH, Pereira AV, Vieira BDG, Rodrigues DP, Marchiori GRS, et al. Proteção à amamentação no espaço prisional: revisão integrativa. Res, Soc Develop. 2020;9(9):e555997692. https://doi.org/10.33448/rsd-v9i9.7692

31. Paynter MJ, Snelgrove CE. “Breastfeeding in public” for incarcerated women: the baby-friendly steps. Int Breastfeed J. 2019;14(16):2-8. https://doi.org/10.1186/s13006-019-0211-3

32. Quadros D, Schimidt L, Deon RG. Prevalência de aleitamento materno em crianças menores de 2 anos de idade. Rev Enferm [Internet]. 2017 [cited 2020 Apr 16];13(13):29-40. Available from: http://www.revistas.fw.uri.br/index.php/revistadeenfermagem/article/view/2903

33. Paynter MJ, Snelgrove C. Breastfeeding support for criminalized women in Canada. J Hum Lact. 2017;33(4):672-6. https://doi. org/10.1177/0890334417726057

34. Mariano GJS, Silva IA. Significando o amamentar na prisão. Texto Contexto Enferm. 2018;27(4):e0590017. https://doi. org/10.1590/0104-07072018000590017 